\title{
Synthesis and Characterization of New Pentacoordinate Iron-Based Aryloxide Complexes
}

\author{
Yvens Chérémond, ${ }^{[\mathrm{a}]}$ Aurélien Crochet, ${ }^{[\mathrm{a}]}$ and Katharina M. Fromm*[a]
}

\begin{abstract}
Heterobimetallic lithium-iron coordination compounds are interesting targets for several reasons: they can be used as precursors for mixed metal oxides, as catalysts, for example, for ring-opening polymerization reactions or to study oxidation/reduction processes. Finally their magnetic properties are also of interest. New heterobimetallic aryloxide complexes, namely $\left[(\text { thf })_{4} \mathrm{Li}_{3} \mathrm{Fe}(\mathrm{OPh})_{3}\left(\mathrm{O}_{2} \mathrm{C}_{6} \mathrm{H}_{4}\right) \mathrm{Cl}\right]_{2}(\mathbf{1})$, [\{(thf $)_{3} \mathrm{Li}_{3^{-}}$ $\left.\mathrm{Fe}(\mathrm{OPh})_{5} \mathrm{Cl}_{3}\right]_{n}(\mathbf{2})$, and $\left[(\mathrm{thf})_{3} \mathrm{Li}_{3} \mathrm{Fe}(\mathrm{OPh})_{6}\right]_{2}$ (3), have been synthesized and characterized by single-crystal X-ray dif-
\end{abstract}

\section{Introduction}

For several decades, intensive research in the chemistry of metal alkoxides or aryloxides ${ }^{[1-8]}$ has developed, because of their interesting potential to serve many different applications for precursors of oxide materials such as $\mathrm{LiCoO}_{2},{ }^{[7,9]}$ as catalysts, ${ }^{[10-13]}$ or as conducting materials. ${ }^{[9,14,15]}$ Metal alkoxides have also been proposed as good precursors for ceramic materials based on high-purity metal oxides, because of their high solubility, low decomposition temperatures, ${ }^{[16]}$ cross linking ability, and ease of modification. ${ }^{[6,17]}$ Several methods have been reported for the synthesis of metal alkoxides and aryloxides. ${ }^{[2-4,6]}$ The synthetic method depends generally on the electronegativity of the metal concerned. High electropositive metals, such as alkali, alkaline earth metals, and lanthanides, react directly with alcohols to liberate a hydrogen molecule and the corresponding metal alkoxide/aryloxide. ${ }^{[2,4,18]}$ Anodic dissolution of the metal ( $\mathrm{Sc}, \mathrm{Y}, \mathrm{Ti}, \mathrm{Fe}, \mathrm{Co}, \mathrm{Ni}, \mathrm{Cu}$ ) by electrochemical routes in dry alcohols and conducting electrolytes appears to be a promising procedure for metal alkoxide synthesis. $^{\text {[2] }}$

Aryloxide ligands are easily available and can form rather stable metal aryloxides with oxygen bridges between different metal ions, ${ }^{[16]}$ a property that can be useful in the construction of metal organic frameworks (MOFs), clusters, and coordination polymer compounds. ${ }^{[19]}$ In order to

[a] Department of Chemistry, Fribourg Center for Nanomaterials FriMat, University of Fribourg,

Chemin du Musée 9, 1700 Fribourg, Switzerland

Fax: +41-26-3009738

E-mail: katharina.fromm@unifr.ch fraction. While compounds $\mathbf{1}$ and $\mathbf{3}$ were synthesized by an oxidative substitution reaction, compound 2 was directly obtained from the $\mathrm{Fe}^{\mathrm{III}}$ salt. These compounds are accessible by both synthetic pathways. Additionally, in compound 1, the phenoxy ligand was catalytically oxidized to ortho-catechol, which was incorporated into the structure of $\mathbf{1}$ as a ligand that coordinates strongly to iron. All compounds feature the $\mathrm{Fe}^{\mathrm{III}}$ ion with a trigonal, bipyramidal environment, with coordination number 5 .

obtain mixed metal oxide materials, the precursors should contain the metal ions in the correct stoichiometric ratio for the formation of the final oxide. Compounds containing a mixture of alkali and transition metal ions present ideal combinations with a view to develop precursors with low decomposition temperatures to yield the mixed metal oxide materials used, for example, in lithium ion batteries. The transition metal ion can easily be varied. Thus, various heterobimetallic compounds based on alkoxide or aryloxide ligands have been reported ${ }^{[2,4,8,15,17,20]}$ for several interesting applications like precursors for porous iron, manganese, or titanium oxides in photocatalysts. ${ }^{[5]}$ The synthesis of the single-molecule-like $\left[(\text { thf }) \mathrm{NaFe}(\mathrm{O} t \mathrm{Bu})_{3}\right]_{2}{ }^{[19]}$ has been evaluated to be a good initiator for controlled ring-opening polymerization of rac-lactide. As cited before, iron alkoxide/ aryloxide complexes have particularly been shown to be interesting for several applications such as precursors for iron oxide nanoparticles, ${ }^{[15,21]}$ or as catalysts. ${ }^{[10,12,13,19]}$

For several years, we have been studying the synthesis of mixed metal compounds ${ }^{[22-24]}$ containing alkali or alkaline earth and transition metal ions in order to generate mixed metal oxides with the intent of making these at much lower temperatures than those employed in the classical solid state synthesis. ${ }^{[15,24]}$ Our general reaction scheme involves a $\mathrm{M}^{\mathrm{II}}$ halide, which is reacted with an alkali alkoxide or aryloxide in a dry solvent such as thf.

\section{$\mathrm{CaI}_{2}+8 \mathrm{LiOPh}+6 \mathrm{thf} \rightarrow\left[\mathrm{Li}_{6} \mathrm{Ca}(\mathrm{OPh})_{8}(\text { thf })_{6}\right]+2 \mathrm{LiI}$}

Thus, we have shown that, for example, a lithium calcium phenoxide compound used as catalyst for the styrene polymerization ${ }^{[25]}$ possesses a bis(heterocubane) structure, based on one calcium and six lithium ions as well as eight $\mathrm{OPh}$ anions, ${ }^{[23]}$ a structure that was hitherto unknown. 
Since then, we have started to transfer this synthetic approach to transition metal halides as starting compounds, successfully using cobalt as transition metal ion to yield $\mathrm{LiCoO}_{2} \cdot{ }^{[26]}$ In parallel, we initiated research on other transition metal halides such as $\mathrm{FeCl}_{2}$ and $\mathrm{FeCl}_{3}$. For the preparation of mixed metal cluster compounds, it is often difficult to predict the stoichiometric ratio with which stable cage compounds or aggregates can be formed. We therefore performed a systematic study, reacting iron chloride with different amounts of $\mathrm{LiOPh}$ in terms of equivalents. The results presented here will refer to the ratios Fe/Li of 1:4, 1:5, and 1:6. As a function of this ratio, different coordination compounds are obtained and described in the following sections.

\section{Results and Discussion}

\section{Fe/Li Ratio of 1:4}

In a first reaction, $\mathrm{FeCl}_{2}$ was treated with four equivalents of $\mathrm{LiOPh}$ in thf. Upon addition of the $1 \mathrm{M}$ solution of $\mathrm{LiOPh}$ in thf to the green solution of $\mathrm{FeCl}_{2}$ in freshly distilled and dry thf, we observed a severe color change to dark red, indicative of the oxidation of $\mathrm{Fe}^{\mathrm{II}}$ to $\mathrm{Fe}^{\mathrm{III}}$. Addition of diethyl ether led to the precipitation of a white powder, identified as $\mathrm{LiCl}$ by powder X-ray diffraction (not shown). Upon layering of the solution with $n$-heptane, the red solution gave brown single crystals of $\left[(\text { thf })_{4} \mathrm{Li}_{3} \mathrm{Fe}-\right.$ $\left.(\mathrm{OPh})_{3}\left(\mathrm{O}_{2} \mathrm{C}_{6} \mathrm{H}_{4}\right) \mathrm{Cl}\right]_{2}$ (1). Compound $\mathbf{1}$ crystallizes in the monoclinic space group $P 2_{1} / c$ with two asymmetric units per unit cell. The asymmetric unit of $\mathbf{1}$ consists of an $\mathrm{Fe}^{\mathrm{III}}$ ion (Fe1), three lithium ions, one chloride ion, four thf molecules, and three phenoxide ligands as well as one pyrocatecholate ligand. The transition metal ion is surrounded by five oxygen atoms, $\mathrm{O} 1$ and $\mathrm{O} 2$ of the catecholate, and $\mathrm{O} 3-$ $\mathrm{O} 5$ of three phenoxide moieties. The five $\mathrm{O}$ atoms form a distorted pentagon around $\mathrm{Fe} 1 . \mathrm{O} 1$ and $\mathrm{O} 2$ act furthermore as bridging atoms to lithium ions Li1 and Li2, respectively, which bear two terminal thf ligands each. Lil completes its coordination sphere by also binding to $\mathrm{O} 5$ of a phenoxide, which is also the bridging ligand to Fe1. Furthermore, the phenoxide moieties $\mathrm{O} 3$ and $\mathrm{O} 4$ connect $\mathrm{Fe} 1$ to Li3. Li2 and $\mathrm{Li} 3$ are both coordinated by $\mathrm{Cl1}$, while $\mathrm{Li} 3$ also connects to the symmetry-equivalent of $\mathrm{Cl1}, \mathrm{Cl1}$ ' (Figure 1). Indeed, a dimer is thus formed through an inversion center located in the geometrical middle of the rhombus formed by Li3, $\mathrm{Cl1}$, Li3', and $\mathrm{Cl1}^{\prime}$. When the bridging chloride ions are included in the description, all lithium ions are coordinated tetrahedrally. Li2, Li3, and $\mathrm{Cl1}$ form an excerpt of a laddertype structure observed in other cluster or coordination polymer compounds. ${ }^{[27]}$

The polyhedra around the metal ions are connected such that the tetrahedra around the lithium ions Li1 and Li3 share an edge with the distorted trigonal bipyramid around $\mathrm{Fe} 1$, while the tetrahedron around Li2 is only connected through a corner, $\mathrm{O} 2$. The distorted polyhedron around $\mathrm{Fe} 1$ can be described with $\mathrm{O} 2$ and $\mathrm{O} 5$ in axial positions, forming an angle of $159.19(9)^{\circ}$, and three $\mathrm{O}$ atoms in equatorial po-
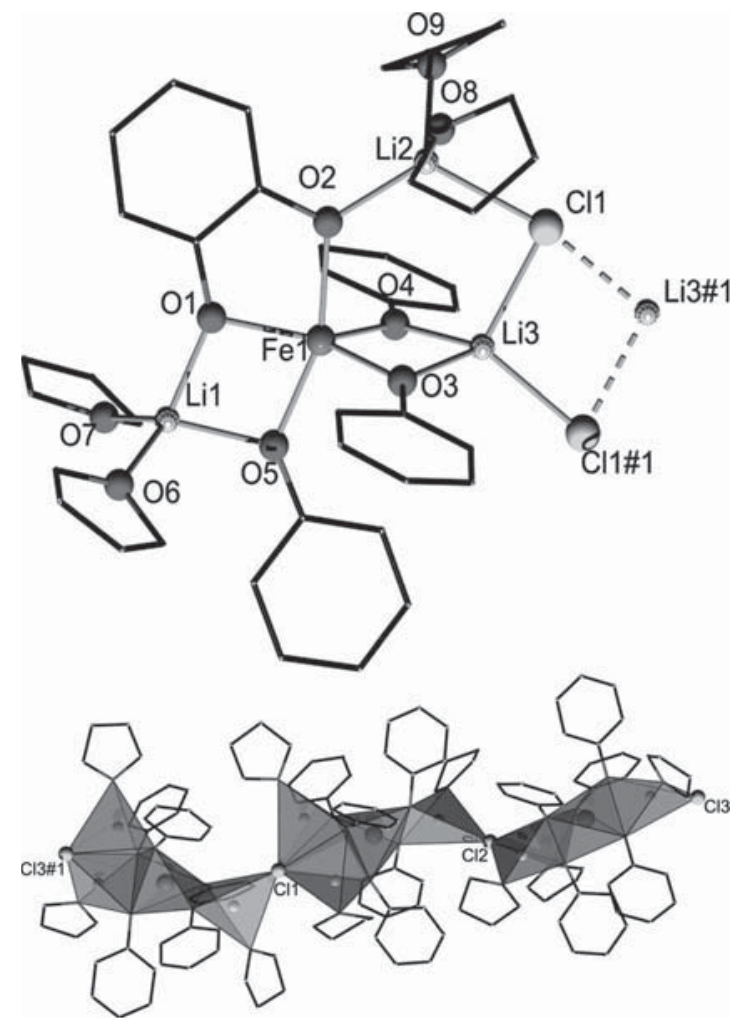

Figure 1. Asymmetric unit of $\mathbf{1}$ (top) and molecular unit of $\mathbf{1}$ (bottom) with omission of hydrogen atoms for clarity (symmetry operation \#1: $-x+1,-y-1,-z)$.

sitions [O1-Fe1-O3 133.6(1) ${ }^{\circ}, \mathrm{O} 3-\mathrm{Fe} 1-\mathrm{O} 4$ 87.38(9) ${ }^{\circ}$, O4Fe1-O1 $\left.138.8(1)^{\circ}\right]$. The strongest deviation from the perfect trigonal-bipyramid is related to the bite angle of the catechol with [O1-Fe1-O2 80.2(9) ${ }^{\circ}$, which compares well with literature data (Figures S1 and S2). ${ }^{[28]}$ The bond valence sum gives a value of 3.02 for $\mathrm{Fe} 1$, showing that the metal ion is well-coordinated.

Clearly, oxidation processes have occurred at different levels in this reaction: in a first step, $\mathrm{Fe}^{\mathrm{II}}$ was oxidized to $\mathrm{Fe}^{\mathrm{III}}$. At this stage, the source of oxidation agents is unclear; it could have been oxygen due to improper transfer of reagents while using the Schlenk technique, but the high yield of the product leaves us in doubt. The second oxidation process, however, might give us hints as to which oxidant was introduced by accident during this reaction: a pyrocatecholate was formed from phenolate. A literature search $^{[29-33]}$ shows that the presence of $\mathrm{Fe}^{\mathrm{II}}$ ions can catalyze the oxidation of phenol to catechol by peroxide, preferentially forming the ortho-substituted product, as we observe in compound $\mathbf{1}$. Given the fact that the oxidation process can be observed directly with the naked eye upon addition of the commercial $1 \mathrm{M}$ solution of $\mathrm{LiOPh}$ in thf, we suspect that peroxide is present, and it stems from the ethereal solvent thf. As the reaction gave good yields, peroxide must have been present in quasi stoichiometric quantities such that; (1) all $\mathrm{Fe}^{\mathrm{II}}$ was oxidized to $\mathrm{Fe}^{\mathrm{III}}$, and (2) $1 / 4$ of the phenolate was oxidized to pyrocatechol on top of that. The reaction scheme for the formation of $\mathbf{1}$ can thus be written as: 
$2 \mathrm{FeCl}_{2}+8 \mathrm{LiOPh}+2 \mathrm{H}_{2} \mathrm{O}_{2}+8$ thf $\rightarrow\left[(\text { thf })_{4} \mathrm{Li}_{3} \mathrm{Fe}(\mathrm{OPh})_{3-}\right.$ $\left.\left(\mathrm{O}_{2} \mathrm{C}_{6} \mathrm{H}_{4}\right) \mathrm{Cl}\right]_{2}(\mathbf{1})+2 \mathrm{LiCl}+2 \mathrm{H}_{2} \mathrm{O}$

\section{Fe/Li Ratio of 1:5}

In order to avoid the oxidation reaction, we directly used $\mathrm{FeCl}_{3}$ and reacted it with $\mathrm{LiOPh}$ in a ratio of 1:5 in thf to obtain brown single crystals of $\left[\left\{(\text { thf })_{3} \mathrm{Li}_{3} \mathrm{Fe}(\mathrm{OPh})_{5} \mathrm{Cl}\right\}_{3}\right]_{n}$ (2), which crystallize in the triclinic space group $P \overline{1}$. The reaction takes place as a complete chloride substitution on the iron atom; however, $\mathrm{LiCl}$ is integrated into the final structure, as given by the following equation.

$3 \mathrm{FeCl}_{3}+15 \mathrm{LiOPh}+9 \mathrm{thf} \rightarrow\left[\left\{(\mathrm{thf})_{3} \mathrm{Li}_{3} \mathrm{Fe}(\mathrm{OPh})_{5} \mathrm{Cl}\right\}_{3}\right]_{n}(\mathbf{2})+6 \mathrm{LiCl}$

The smallest unit of $\mathbf{2}$ consists, as in $\mathbf{1}$, of one iron and three lithium ions, bridged to each other by oxygen atoms. Thus, $\mathrm{Fe} 1$ is connected to Lil by the phenoxide groups $\mathrm{O} 1$ and $\mathrm{O} 2$, to $\mathrm{Li} 2$ by $\mathrm{O} 2$ and $\mathrm{O} 3$, and to $\mathrm{Li} 3$ by $\mathrm{O} 4$ and $\mathrm{O} 5$. Among the five phenoxide moieties, only $\mathrm{O} 2$ is $\mu_{3}$-bridging, while the others act as simple bridging ligands. Each lithium ion carries a terminal thf ligand (Figure 2).

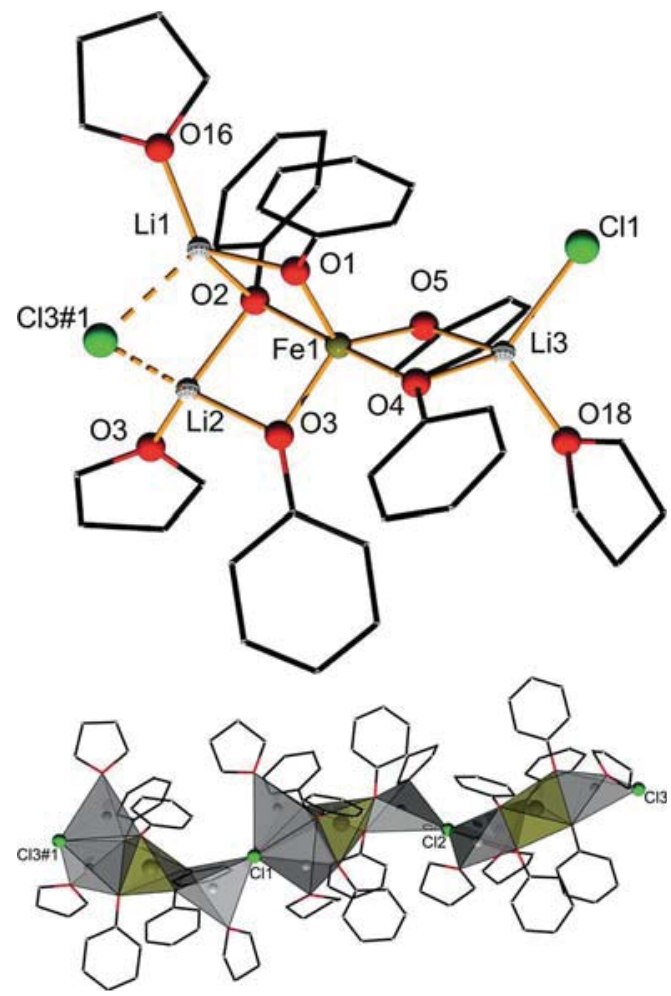

Figure 2. Primary monomeric unit (top) of the 1D coordination polymer of compound $\mathbf{2}$ and its polyhedral arrangement (bottom) with omission of hydrogen atoms for clarity.

Both Li1 and Li2 are also linked to a chloride ion, $\mathrm{Cl} 3$, such that $\mathrm{Fe} 1, \mathrm{Li} 1, \mathrm{Li} 2, \mathrm{O} 1-\mathrm{O} 3$, and $\mathrm{Cl} 3$ form an open, distorted heterocubane structure with one missing corner. On the other side of the aggregate, Li3 binds to C11 of the next similar unit. Three such entities, formed around Fe1, $\mathrm{Fe} 2$, and $\mathrm{Fe} 3$, are connected to each other in a zigzag fashion, and in the end, the third unit is connected to the symmetry-equivalent of the first. In this way, a one-dimensional coordination polymer is obtained. The first basic unit with $\mathrm{Fe} 1$ is distorted with respect to the basic unit around $\mathrm{Fe} 2$ with a torsion angle of $113.2(2)^{\circ}$, which is itself twisted against the third unit of $\mathrm{Fe} 3$ with a torsion angle of $112.6(2)^{\circ}$.

It is surprising that, although an excess of $\mathrm{LiOPh}$ was used to eliminate all chloride, one chloride per unit remains in the final structure. On the other hand, a polymeric structure could be obtained here. The formation of catecholate is not observed in this case; therefore, there should be no constrained bite angles here. Indeed, the geometry around the iron atoms $\mathrm{Fe} 1, \mathrm{Fe} 2$, and $\mathrm{Fe} 3$ presents three almost linear $\mathrm{O}-\mathrm{Fe}-\mathrm{O}$ angles ranging from $176.4(2)^{\circ}$ to $177.3(2)^{\circ}$. The angles between equatorially positioned $\mathrm{O}$ atoms lie between 111.9(2) and $129.1(2)^{\circ}$.

\section{Fe/Li Ratio of 1:6}

If $\mathrm{FeCl}_{2}$ is reacted in a ratio of $1: 6$ with $\mathrm{LiOPh}$ in the, a full substitution oxidation product, $\left[(\mathrm{thf})_{3} \mathrm{Li}_{3} \mathrm{Fe}(\mathrm{OPh})_{6}\right]_{2}(3)$, is obtained in good yield by oxidation.

$2 \mathrm{FeCl}_{2}+12 \mathrm{LiOPh}+6$ thf $+\left(1 / 2 \mathrm{O}_{2}\right.$ or $\left.\mathrm{H}_{2} \mathrm{O}_{2}\right) \rightarrow\left[(\text { thf })_{3^{-}}\right.$ $\left.\mathrm{Li}_{3} \mathrm{Fe}(\mathrm{OPh})_{6}\right]_{2}(3)+4 \mathrm{LiCl}+\left(\mathrm{Li}_{2} \mathrm{O}\right.$ or $\left.2 \mathrm{LiOH}\right)$

This time, oxidation of $\mathrm{Fe}^{\mathrm{II}}$ to $\mathrm{Fe}^{\mathrm{III}}$ occurs as the only oxidation process. The structure still resembles compound 1 and 2: again, the iron ion $\mathrm{Fe} 1$ has a pentagonal coordination sphere with five $\mathrm{O}$ atoms, $\mathrm{O} 1-\mathrm{O} 5$, stemming from five phenoxide ligands (Figure 3). Less distorted than in 1, the $\mathrm{O} 1-\mathrm{Fe} 1-\mathrm{O} 4$ angle is $179.5(2)^{\circ}$, and the angles between the equatorially placed phenoxides are found to reach from $110.6(2)^{\circ}$ to $124.7(2)^{\circ}$. O1 and $\mathrm{O} 2$ act as bridging ligands between $\mathrm{Fe} 1$ and Li1, to which two terminal thf ligands are also coordinated. $\mathrm{O} 3, \mathrm{O} 4$, and $\mathrm{O} 5$ connect $\mathrm{Fe} 1$ to $\mathrm{Li} 2$ and Li3, which are both bridged by phenoxide O6. In this way, an open heterocubane structure with a missing corner is formed by $\mathrm{Fe} 1, \mathrm{Li} 2, \mathrm{Li} 3$, and $\mathrm{O} 3, \mathrm{O} 4, \mathrm{O} 5$, and $\mathrm{O} 6$. While $\mathrm{Li} 2$ carries a terminal thf to complete its tetrahedral coordination sphere, Li3 is connected to O6\#1 via an inversion center found in the middle of the rhombus Li3-O6-Li3\#1O6\#1. The phenoxide of O6 in compound 3 plays thus a similar role to that of $\mathrm{Cl1}$ in compound 1, linking the two molecular units into a dimeric entity.

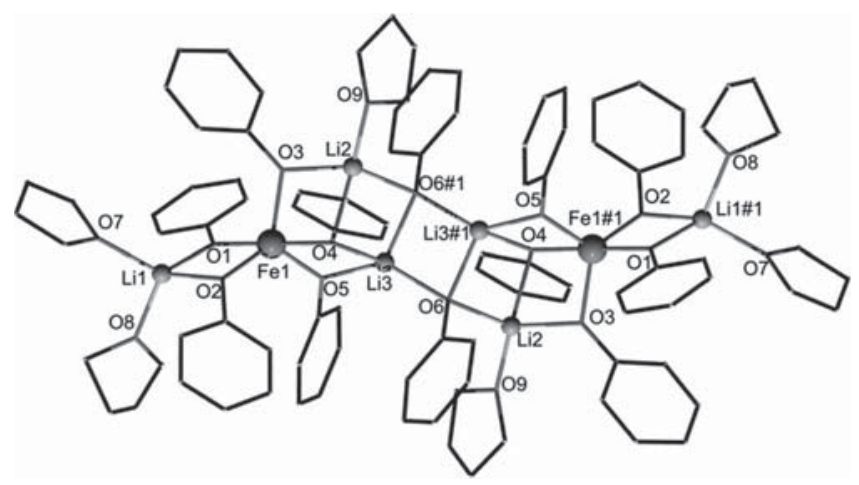

Figure 3. View of dimeric compound 3. 
For all reactions starting from $\mathrm{Fe}^{\mathrm{II}}$, complete oxidation of the metal ion was observed, and also the oxidation of phenol to catechol for compound $\mathbf{1}$. This reaction can happen in the presence of metal ions as catalysts and with $\mathrm{H}_{2} \mathrm{O}_{2}$ as oxidant. We propose, on the basis of literature data, ${ }^{\text {[29-33] }}$ a reaction mechanism, shown in Scheme 1, for the oxidation.
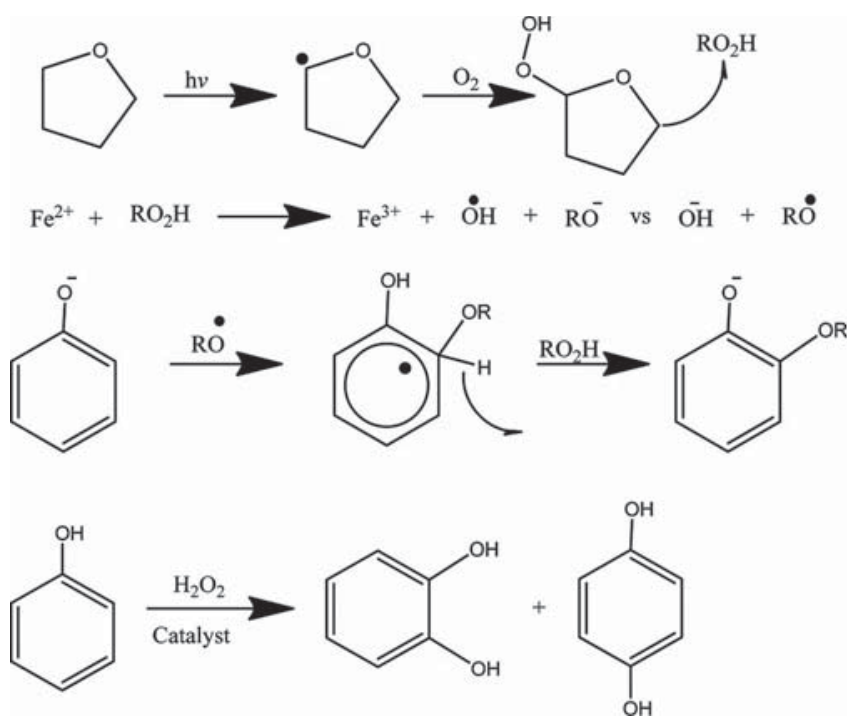

Scheme 1.

While catechol was formed during the first reaction, this ligand was not observed in the other two reactions, thus leading to compounds $\mathbf{2}$ and $\mathbf{3}$. Given the extremely good sequestering/chelating properties of catechol with iron ions, we would have expected to find this ligand, if it had formed, coordinated to the iron ions. This was not the case, and ${ }^{13} \mathrm{C}$ NMR spectroscopic studies also do not confirm the presence of this ligand.

To elucidate the oxidation processes, we tested the initial $1 \mathrm{M} \mathrm{LiOPh}$ solution in thf for the presence of peroxide. A peroxide strip test did not give a positive response. We therefore suspect that peroxide formed in the thf used as solvent after storage over several days. All of our compounds exhibit a pentacoordinate $\mathrm{Fe}^{\mathrm{III}}$ ion with five O-donors surrounding it. Such a coordination is unique to the best of the authors' knowledge, as other reported $\mathrm{Fe}^{\mathrm{III}}$ compounds with coordination number five have $\mathrm{N}$ - and O-donors. ${ }^{[34-37]}$ Other purely O-donor-coordinated $\mathrm{Fe}^{\mathrm{III}}$ compounds have coordination numbers of four, based, for example, on sterically demanding $\mathrm{O} t \mathrm{Bu}$ ligands. ${ }^{[38,39]}$ Pentacoordinate $\mathrm{Fe}^{\mathrm{III}}$ compounds are highly exciting compounds, as they are the main players in crucial applications such as oxygen transport in blood (non-heme) ${ }^{[35,40]}$ enzymes, ${ }^{[37]}$ and catalysts. ${ }^{[29-33]}$ Complexes with coordination number five can process two different geometries, either square pyramidal or trigonal bipyramidal. The most active compounds feature the square pyramid around the metal ion, whereas the trigonal bipyramidal compounds seem to be less active. In order to decide whether a compound with distorted geometry is rather one or the other, the geometry factor $\tau$ can be calculated. ${ }^{[41]}$ While our compounds 2 and 3 with $\tau$ between 0.79 for $\mathrm{Fe} 3$ and 0.89 for $\mathrm{Fe} 1$ in 2, respectively, and $\tau=0.91$ for 3 can be rather classified as trigonal bipyramidal, compound $\mathbf{1}$ has a $\tau$ value of 0.31 . It is thus closer to square pyramidal than trigonal bipyramidal and might exhibit exciting properties in terms of catalysis. This research is ongoing in our laboratory.

In the three compounds, the tetrahedrally coordinated $\mathrm{Li}$ atoms form $\mathrm{Li}-\mathrm{O}$ bonds (Table 1) with bond lengths that fall into the ranges known from the literature $(1.93 \AA$, cf. histogram in Figure S2), except for the $\mathrm{Li4}-\mathrm{O} 7\left(\mu_{3}\right)$ of 2.126(2) $\AA$ in the central open heterocubane of compound 2. The longest Fe1-Li2 distance of 3.505(7) $\AA$ in compound $\mathbf{1}$ is found in the six-membered ring formed by Fe1, O3(or O4), Li3, C11, Li2, and O2, whereas the other structural features are $\mathrm{Fe}-\mathrm{O}-\mathrm{Li}-\mathrm{O}$ rhombi, in which these distances are shorter. The $\mathrm{Fe}-\mathrm{O}$ bond lengths (Table 1) are also similar to those in the literature (cf. histogram in Figure S2), but very few papers report $\mathrm{Fe}-\mathrm{O}$ bond lengths below $1.90 \AA$ as shown for equatorial $\mathrm{Fe}-\mathrm{O}$ bonds in compounds $\mathbf{1}$ and 2. Only $\left[\mathrm{FeLi}_{2} \mathrm{Br}\left(\mathrm{C}_{4} \mathrm{H}_{9} \mathrm{O}\right)_{4}\left(\mathrm{C}_{4} \mathrm{H}_{8} \mathrm{O}\right)_{2}\right]_{n}{ }^{[39]}$ has similarly short $\mathrm{Fe}-\mathrm{O}$ distances in the range 1.8616(11)-1.8687(11) $\AA$.

Table 1. Selected atomic distance ranges of $\mathbf{1}, \mathbf{2}$, and $\mathbf{3}$ in $\AA$.

\begin{tabular}{llll}
\hline Compound & $\mathbf{1}$ & $\mathbf{2}$ & $\mathbf{3}$ \\
\hline Fe-Li & $2.807(4)-3.505(7)$ & $2.86(1)-2.96(1)$ & $2.92(1)-2.95(1)$ \\
Fe-O (eq.) & $1.898(2)-1.958(2)$ & $1.884(5)-1.915(5)$ & $1.902(4)-1.916(4)$ \\
Fe-O (ax.) & $1.967(3)-2.014(3)$ & $1.916(4)-2.058(4)$ & $1.944(4)-2.019(4)$ \\
Li-O & $1.902(8)-1.966(8)$ & $1.85(2)-2.126(2)$ & $1.921(1)-1.954(1)$ \\
Li-Cl & $2.307(5)-2.377(7)$ & $2.34(2)-2.37(1)$ & none \\
\hline
\end{tabular}

\section{Conclusions}

Starting from $\mathrm{Fe}^{\mathrm{II}}$ and $\mathrm{Fe}^{\mathrm{III}}$ chloride, we were able, through oxidation and/or substitution reactions, to obtain three new $\mathrm{Fe}^{\mathrm{III}}$ coordination compounds. All of these compounds possess a pentagonal coordination sphere around the transition metal ion based on five O-donor atoms. In compound 1 we observed the iron-catalyzed oxidation of phenolate to catecholate, in compound $\mathbf{2}$ a substitution reaction occurred, and in compound $\mathbf{3}$ oxidation and substitution were observed. Whereas compound $\mathbf{2}$ and $\mathbf{3}$ have distorted trigonal bipyramidal coordination spheres around the Fe atom, compound $\mathbf{1}$ exhibits distorted square-pyramidal geometry, offering the possibility for catalytic reactions.

\section{Experimental Section}

Materials and Characterizations: All reagents and solvents were bought from Aldrich, except for the $\mathrm{FeCl}_{2}$, which was bought from Fluka and the thf solvent, which was stored in molecular sieves type 4A from Fluka. All experiments were run under an inert atmosphere with use of a glove box and the Schlenk technique. ${ }^{[42]}$

General Synthesis Procedure: All the materials were synthesized by using a modified version of the method of Gun'ko et al. ${ }^{[38]}$ We used a $1 \mathrm{M}$ solution of lithium phenoxide in thf from Sigma Aldrich. Solvent thf was used as the main synthesis solvent, and the 
crystallizations were performed by solvent diffusion. After a few weeks, dark-brown single crystals appeared in the Schlenk flask.

[(thf $\left.)_{4} \mathbf{L i}_{3} \mathbf{F e}(\mathbf{O P h})_{3}\left(\mathbf{O}_{2} \mathbf{C}_{\mathbf{6}} \mathbf{H}_{\mathbf{4}}\right) \mathbf{C l}\right]_{\mathbf{2}}$ (1): $\mathrm{FeCl}_{2} \quad(1.01 \mathrm{mmol}, 128 \mathrm{mg})$ was dissolved in an excess of thf $(15 \mathrm{~mL})$. Then, this solution was kept under reflux for $15 \mathrm{~min}$. Lithium phenoxide $(3 \mathrm{mmol}, 3 \mathrm{~mL}$, $1 \mathrm{M})$ was added by using a syringe through a septum under argon flow, and the solution spontaneously became dark red. The dark red solution was been kept under reflux for 30 min to complete the reaction. After cooling to room temperature, diethyl ether $(10 \mathrm{~mL})$ was added to accelerate the precipitation of $\mathrm{LiCl}$, which allowed the solution to be filtered. The remaining solution was concentrated by evaporation of thf under vacuum, and heptane $(10 \mathrm{~mL})$ was slowly added without mixing for liquid/liquid diffusion crystallization. Dark brown cubic crystals appeared after a few weeks. IR: $\tilde{v}=$ 3583 (w), 3058 (w), 2876 (w), 1588 (m), 1479 (g), 1254 (h), 1166 (sh), 1041 (m), 875 (sh), 753 (sh), 729 (sh), 688 (s)618 (w), 587 (s) $\mathrm{cm}^{-1}$.

Peroxide Test: A peroxide test was performed on the stored thf with benzophenone from ACROS in presence of sodium from Fluka. This test revealed the presence of peroxide by the characteristically yellow-colored solution.

$\left[\left\{(\text { thf })_{3} \mathrm{Li}_{3} \mathrm{Fe}(\mathrm{OPh})_{5} \mathrm{Cl}_{3} \boldsymbol{l}_{\boldsymbol{n}}\right.\right.$ (2): $\mathrm{FeCl}_{3}(1.12 \mathrm{mmol}, 182 \mathrm{mg})$ was dissolved in thf $(10 \mathrm{~mL})$ under reflux and stirred for $5 \mathrm{~min}$, then ( $5 \mathrm{~mL}, 5 \mathrm{mmol}, 1 \mathrm{M})$ of lithium phenoxide was added, and the solution was kept under reflux with stirring for $5 \mathrm{~min}$. After cooling to room temperature, the solution was kept at $-24{ }^{\circ} \mathrm{C}(249 \mathrm{~K})$ for $24 \mathrm{~h}$. A white precipitate of $\mathrm{LiCl}$ formed. The solution was filtered and kept at $24{ }^{\circ} \mathrm{C}$ for crystallization. IR: $\tilde{v}=3582$ (sh), 3300 (w), 3022 (w), 1587 (m), 1478 (h), 1234 (w), 1164 (sh), 1071 (sh), 845 (w), 751 (sh), 668 (sh), 630 (w) $\mathrm{cm}^{-1}$.

[(thf) ${ }_{3} \mathbf{L i}_{3} \mathbf{F e}(\mathbf{O P h})_{6} \mathbf{l}_{\mathbf{2}}$ (3): $\mathrm{FeCl}_{2}(0.95 \mathrm{mmol}, 120 \mathrm{mg})$ was dissolved partially in lithium phenoxide solution in thf $(4 \mathrm{~mL}, 1 \mathrm{M})$ under reflux for a few minutes, and the excess of $\mathrm{FeCl}_{2}$ was filtered off. The solvent thf was evaporated. The complex was extracted with a mixture of heptane and diethyl ether $(10 \mathrm{~mL})$ in a ratio of $4: 1$, respectively. The solution was kept at room temperature until crystallization. IR: $\tilde{v}=3583$ (sh), 3306 (w), 2957 (w), 2924 (w), 2336 (w), 1588 (m), 1478 (h), 1249 (m), 1164 (sh), 758 (sh), 690 (sh), $618(\mathrm{sh}) \mathrm{cm}^{-1}$.

Single-Crystal X-ray Structures: All single crystals suitable for Xray measurement were mounted on loops. Data was collected at $200 \mathrm{~K}$ with a STOE IPDS II and IPDS IIT diffractometer equipped with an Oxford Cryosystem open flow cryostat. ${ }^{[43]}$ Structures were solved and refined with ShelX 97 software $^{[44]}$ by using PLATON ${ }^{[45]}$ to change space group from $P 2_{1} / n$ to $P 2_{1} / c$ (1) program with the version 4.0.6 to confirm the oxidation state of the metal ions. Hydrogen atoms were introduced as fixed contributors, when a residual electronic density was observed near their expected positions. Table 2 contains the crystallographic data of the structure analyses of compounds $\mathbf{1}-\mathbf{3}$. Disorders of the coordinated thf in compound $\mathbf{2}$ are responsible for the high $R$ value.

CCDC-846169 (for 1), -846170 (for 3), and -846171 (for 2) contain the supplementary crystallographic data for this paper. These data can be obtained free of charge from The Cambridge Crystallographic Data Centre via www.ccdc.cam.ac.uk/data_request/cif.

Table 2. Crystal data for $\mathbf{1}, \mathbf{2}$, and $\mathbf{3}$.

\begin{tabular}{|c|c|c|c|}
\hline & Compound 1 & Compound 2 & Compound 3 \\
\hline Empirical formula & $\mathrm{C}_{80} \mathrm{H}_{102} \mathrm{Cl}_{2} \mathrm{Fe}_{2} \mathrm{Li}_{6} \mathrm{O}_{18}$ & $\mathrm{C}_{126} \mathrm{H}_{147} \mathrm{Cl}_{3} \mathrm{Fe}_{3} \mathrm{Li}_{9} \mathrm{O}_{24}$ & $\mathrm{C}_{96} \mathrm{H}_{108} \mathrm{Fe}_{2} \mathrm{Li}_{6} \mathrm{O}_{18}$ \\
\hline Formula weight & 1575.89 & 2381.80 & 1703.24 \\
\hline Temperature $[\mathrm{K}]$ & $200(2)$ & $200(2)$ & $200(2)$ \\
\hline Wavelength [Å] & 0.71073 & 0.71073 & 0.71073 \\
\hline Crystal system & monoclinic & triclinic & monoclinic \\
\hline Space group & $P 2_{1} / c$ & $P \overline{1}$ & $P 2_{1} / n$ \\
\hline$a[\AA]$ & $13.9413(3)$ & $13.1905(5)$ & $12.9186(5)$ \\
\hline$b[\AA]$ & $14.8463(4)$ & $22.2229(8)$ & $24.2037(10)$ \\
\hline$c[\AA]$ & $21.9353(6)$ & $23.8116(8)$ & $15.7110(6)$ \\
\hline$\alpha\left[^{\circ}\right]$ & 90 & 109.958(3) & 90 \\
\hline$\beta\left[^{\circ}\right]$ & 114.793(3) & $99.584(3)$ & $106.03(3)$ \\
\hline$\gamma\left[^{\circ}\right]$ & 90 & $98.114(3)$ & 90 \\
\hline Volume $\left[\AA^{3}\right]$ & 4121.63(18) & $6319.8(4)$ & $4721.5(3)$ \\
\hline$Z$ & 2 & 2 & 2 \\
\hline Density (calculated) $\left[\mathrm{Mg} \mathrm{m}^{-3}\right]$ & 1.270 & 1.251 & 1.198 \\
\hline Absorption coefficient $\left[\mathrm{mm}^{-1}\right]$ & 0.481 & 0.470 & 0.371 \\
\hline$F(000)$ & 1660 & 2498 & 1796 \\
\hline Crystal size $\left[\mathrm{mm}^{3}\right]$ & $0.550 \times 0.543 \times 0.430$ & $0.05 \times 0.03 \times 0.02$ & $0.230 \times 0.203 \times 0.180$ \\
\hline Theta range for data collection & 1.37 to $25.73^{\circ}$ & 1.08 to $24.70^{\circ}$ & 2.00 to $22.50^{\circ}$ \\
\hline \multirow[t]{3}{*}{ Index ranges } & $-16 \leq h \leq 16$ & $-15 \leq h \leq 15$ & $-13 \leq h \leq 13$ \\
\hline & $-17 \leq k \leq 0$ & $-25 \leq k \leq 25$ & $-26 \leq k \leq 26$ \\
\hline & $-26 \leq l \leq 15$ & $-27 \leq l \leq 27$ & $-16 \leq l \leq 16$ \\
\hline Reflections collected & 83923 & 81104 & 51457 \\
\hline Independent reflections & $7209[R($ int $)=0.1129]$ & $21008[R(\mathrm{int})=0.0601]$ & $6067[R($ int $)=0.0673]$ \\
\hline Completeness to $\theta=24.70^{\circ}$ & $99.30 \%$ & $98.9 \%$ & $98.40 \%$ \\
\hline Refinement method & full-matrix least squares on $F^{2}$ & full-matrix least squares on $F^{2}$ & full-matrix least squares on $F^{2}$ \\
\hline Data/restraints/parameters & $7209 / 0 / 487$ & $19926 / 0 / 1474$ & $6067 / 0 / 550$ \\
\hline Goodness-of-fit on $F^{2}$ & 0.821 & 0.963 & 0.969 \\
\hline Final $R$ indices $[I>2 \sigma(I)]$ & $R_{1}^{[\mathrm{a}]}=0.0559, w R_{2}^{[\mathrm{b}]}=0.1400$ & $R_{1}=0.1162, w R 2=0.2627$ & $R_{1}=0.0864, w R 2=0.2074$ \\
\hline$R$ indices (all data) & $R_{1}=0.0827, w R 2=0.1486$ & $R_{1}=0.1363, w R 2=0.2982$ & $R_{1}=0.1125, w R 2=0.2353$ \\
\hline Bond valence sum (BVS) Fel & 3.02 & 3.17 & 3.11 \\
\hline Largest diff. peak and hole $\left[\mathrm{e} \AA^{-3}\right]$ & 0.240 and -0.851 & 0.236 and -0.896 & 0.401 and -0.480 \\
\hline
\end{tabular}

[a] $R=\Sigma\left(\left|F_{\mathrm{o}}\right|-\mid F_{\mathrm{c}}\right) / \sum\left(F_{\mathrm{o}}\right)$. [b] $w R=\left\{\Sigma\left[w\left(F_{\mathrm{o}}{ }^{2}-F_{\mathrm{c}}{ }^{2}\right)^{2}\right] / \Sigma\left[w\left(F_{\mathrm{o}}{ }^{2}\right)^{2}\right]\right\}^{1 / 2}$. 
Bond Valence Sums: The bond valence sums were calculated by the Valist program. ${ }^{[46]}$

Supporting Information (see footnote on the first page of this article): Additional views of the structures of compounds $\mathbf{1}$ and $\mathbf{3}$, histogram of bite angles, NMR and XRPD spectra, scheme of the Berry pseudorotation in trigonal bipyramidal iron complexes, and bond lengths for compounds $\mathbf{1}, \mathbf{2}$, and $\mathbf{3}$.

\section{Acknowledgments}

The authors thank the Swiss National Science Foundation, the University of Fribourg, and Fribourg Center for Nanomaterials (FriMat) for financial and technical support.

[1] a) T.-J. Hsiao, J.-C. Tsai, J. Appl. Polym. Sci. 2010, 116, 20402049; b) A. Kumar, A. G. Samuelson, Chem. Asian J. 2010, 5, 1830-1837; c) P. Sobota, A. Drag-Jarzabek, L. John, J. Utko, L. B. Jerzykiewicz, M. Duczmal, Inorg. Chem. 2009, 48, 6584 6593; d) L.-L. Chen, L.-Q. Ding, C. Zeng, Y. Long, X.-Q. Lue, J.-R. Song, D.-D. Fan, W.-J. Jin, Appl. Organomet. Chem. 2011, 25, 310-316; e) M. Beesu, M. Periasamy, J. Org. Chem. 2011, 76, 543-549; f) D. C. Bradley, R. Mehrotra, D. Gaur, Metal alkoxides, Academic Press, London, 1978.

[2] D. Bradley, Alkoxo and Aryloxo Derivatives of Metals, Academic Press, San Diego, 2001.

[3] M. H. Chisholm, D. C. Bradley, Polyhedron 1998, 17, 6231034.

[4] N. J. Turova, The Chemistry of Metal Alkoxides, Kluwer Academic Publishers, Boston, 2002.

[5] X.-X. Zou, G.-D. Li, M.-Y. Guo, X.-H. Li, D.-P. Liu, J. Su, J.S. Chen, Chem. Eur. J. 2008, 14, 11123-11131.

[6] T. J. Boyle, L. A. M. Ottley, Chem. Rev. 2008, 108, 1896-1917.

[7] Ł. John, J. Utko, S. Szafert, L. B. Jerzykiewicz, L. Kpiński, P. Sobota, Chem. Mater. 2008, 20, 4231-4239.

[8] U. Schubert, Acc. Chem. Res. 2007, 40, 730-737.

[9] T. J. Boyle, M. A. Rodriguez, D. Ingersoll, T. J. Headley, S. D. Bunge, D. M. Pedrotty, S. M. De'Angeli, S. C. Vick, H. Fan, Chem. Mater. 2003, 15, 3903-3912.

[10] A. Arbaoui, C. Redshaw, M. R. J. Elsegood, V. E. Wright, A. Yoshizawa, T. Yamato, Chem. Asian J. 2010, 5, 621-633.

[11] a) D. Boutarfa, C. Paillet, M. Leconte, J. M. Basset, J. Mol. Catal. 1991, 69, 157-169; b) B. Zhao, X. L. Hu, C. R. Lu, J. Appl. Polym. Sci. 2011, 120, 2693-2698; c) R. H. Platel, A. J. P. White, C. K. Williams, Inorg. Chem. 2011, 50, 7718-7728.

[12] J. S. Choi, S. S. Yoon, S. H. Jang, W. S. Ahn, Catal. Today 2006, 111, 280-287.

[13] X. Y. Wang, K. R. Liao, D. P. Quan, Q. Wu, Acta Polym. Sin. 2006, 229-235.

[14] a) S. Fortier, G. Wu, T. W. Hayton, Inorg. Chem. 2009, 48, 3000-3011; b) S. Lateskey, J. Keddington, A. K. McMullen, I. P. Rothwell, J. C. Huffman, Inorg. Chem. 1985, 24, 995-1001; c) B. Zheng, M. O. Miranda, A. G. DiPasquale, J. A. Golen, A. L. Rheingold, L. H. Doerrer, Inorg. Chem. 2009, 48, 4274 4276.

[15] T. J. Boyle, L. A. M. Ottley, C. A. Apblett, C. A. Stewart, S. M. Hoppe, K. L. Hawthorne, M. A. Rodriguez, Inorg. Chem. 2011, 50, 6174-6182.

[16] J. Campora, M. L. Reyes, T. Hackl, A. Monge, C. Ruiz, Organometallics 2000, 19, 2950-2952.

[17] D. C. Bradley, Chem. Rev. 1989, 89, 1317-1322.

[18] K. M. Fromm, E. D. Gueneau, Polyhedron 2004, 23, 1479 1504.
[19] D. S. McGuinness, E. L. Marshall, V. C. Gibson, J. W. Steed, J. Polym. Sci. Polym. Chem. Ed. 2003, 41, 3798-3803.

[20] L. Stoicescu, C. Duhayon, L. Vendier, A. Tesouro-Vallina, J.-P. Costes, J.-P. Tuchagues, Eur. J. Inorg. Chem. 2009, 5483-5493.

[21] F.-w. Wang, C.-g. Zhu, M. Xu, W.-y. Fang, J. North Univ. China, Nat. Sci. 2010, 31, 265-268.

[22] a) K. M. Fromm, Dalton Trans. 2006, 5103-5112; b) K. M. Fromm, CrystEng Comm 2002, 4, 318-322.

[23] W. Maudez, M. Meuwly, K. M. Fromm, Chem. Eur. J. 2007, $13,8302-8316$

[24] K. M. Fromm, Chimia 2002, 56, 676-680.

[25] M. Jimenez-Tenorio, M. C. Puerta, I. Salcedo, P. Valerga, S. I. Costa, L. C. Silva, P. T. Gomes, Organometallics 2004, 23, 3139-3146.

[26] a) A. Crochet, Université de Fribourg, Fribourg, Suisse, 2010; b) A. Crochet, J. P. Brog, K. M. Fromm, 01043/10.

[27] N. W. Mitzel, C. Lustig, Z. Naturforsch. Teil B 2001, 56, 443 445

[28] a) M. Teintze, M. B. Hossain, C. L. Barnes, J. Leong, D. van der Helm, Biochemistry 1981, 20, 6446-6457; b) B. F. Anderson, D. A. Buckingham, G. B. Robertson, J. Webb, Acta Crystallogr., Sect. B 1982, 38, 1927-1931; c) T. M. Hoette, R. J. Abergel, J. Xu, R. K. Strong, K. N. Raymond, J. Am. Chem. Soc. 2008, 130, 17584-17592; d) D. L. Caulder, R. E. Powers, T. N. Parac, K. N. Raymond, Angew. Chem. 1998, 110, 1940; Angew. Chem. Int. Ed. 1998, 37, 1840-1843.

[29] S. Bhattacharjee, J.-S. Choi, S.-T. Yang, S. B. Choi, J. Kim, W.S. Ahn, J. Nanosci. Nanotechnol. 2010, 10, 135-141.

[30] H. Shi, T. Zhang, B. Li, X. Wang, M. He, M. Qiu, Catal. Commun. 2011, 12, 1022-1026.

[31] T. A. Enache, A. M. Oliveira-Brett, J. Electroanal. Chem. 2011, $655,9-16$

[32] H. S. Abbo, S. J. Titinchi, S. Chand, R. Prasad, J. Mol. Catal. A 2004, 218, 125-132.

[33] G. La Monica, M. A. Angaroni, F. Cariati, S. Cenini, G. A. Ardizzoia, Inorg. Chim. Acta 1988, 148, 113-118.

[34] a) T. Liu, B. Li, C. V. Popescu, A. Bilko, L. M. Pérez, M. B. Hall, M. Y. Darensbourg, Chem. Eur. J. 2010, 16, 3083-3089; b) A. Abu-Surrah, K. A. Ibrahim, M. Y. Abdalla, A. A. Issa, J. Polym. Res. 2011, 18, 59-66; c) I. Siewert, C. Limberg, Angew. Chem. 2008, 120, 8071; Angew. Chem. Int. Ed. 2008, 47, 7953-7956

[35] E. W. Yemeli Tido, E. J. Vertelman, A. Meetsma, P. J. van Koningsbruggen, Inorg. Chim. Acta 2007, 360, 3896-3902.

[36] F. H. Ishiruji, D. J. Evans, F. L. Benedito, F. S. Nunes, Spectrochim. Acta Part A 2008, 70, 1029-1033.

[37] T. Wondimagegn, A. Rauk, J. Phys. Chem. B 2011, 115, 569579 .

[38] Y. K. Gun'ko, U. Cristmann, V. G. Kessler, Eur. J. Inorg. Chem. 2002, 1029-1031.

[39] H. R. L. Barley, A. R. Kennedy, R. E. Mulvey, Acta Crystallogr., Sect. C 2005, 61, m346.

[40] R. Biswas, M. G. B. Drew, C. Estarellas, A. Frontera, A. Ghosh, Eur. J. Inorg. Chem. 2011, 2558-2566.

[41] A. W. Addison, T. N. Rao, J. Reedijk, J. van Rijn, G. C. Verschoor, J. Chem. Soc., Dalton Trans. 1984, 1349.

[42] D. F. Shriver, M. A. Drezdzon, The Manipulation of Air-Sensitive Compounds, Wiley, New York, NY, 1986.

[43] J. Cosier, A. M. Glazer, J. Appl. Crystallogr. 1986, 19, 105-107.

[44] G. M. Sheldrick, T. R. Schneider, Methods Enzymol. 1997, 277, 319-343.

[45] A. L. Spek, Acta Crystallogr., Sect. D 2009, 65, 148-155.

[46] I. D. Brown, D. Altermatt, Acta Crystallogr., Sect. B 1985, 41, 244-247. 
Pentacoordinate Iron Aryloxides

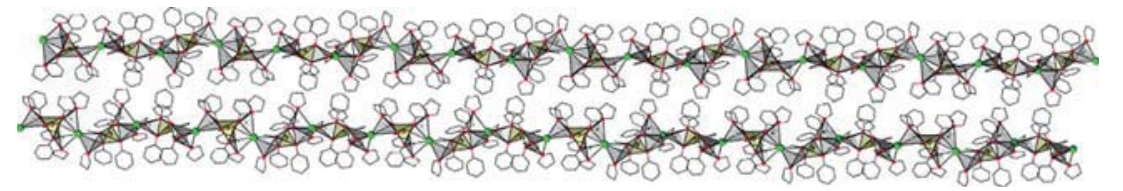

Three new pentacoordinate $\mathrm{Fe}^{\mathrm{III}}$ complexes, $\left[(\text { thf })_{4} \mathrm{Li}_{3} \mathrm{Fe}(\mathrm{OPh})_{3}\left(\mathrm{O}_{2} \mathrm{C}_{6} \mathrm{H}_{4}\right) \mathrm{Cl}\right]_{2}$ (1), $\left[\left\{(\text { thf })_{3} \mathrm{Li}_{3} \mathrm{Fe}(\mathrm{OPh})_{5} \mathrm{Cl}\right\}_{3}\right]_{\mathrm{n}}(\mathbf{2})$, and $\left[(\mathrm{thf})_{3^{-}}\right.$ $\left.\mathrm{Li}_{3} \mathrm{Fe}(\mathrm{OPh})_{6}\right]_{2}(3)$, two dinuclear, molecular species (1 and $\mathbf{3})$ and one trinuclear 1D co- ordination polymer, are reported. Compound 1 has a coordination sphere close to a square pyramid and might thus be useful for applications such as catalyst for the ring-opening polymerization of lactide.
Y. Chérémond, A. Crochet,

K. M. Fromm*

Synthesis and Characterization of New Pentacoordinate Iron-Based Aryloxide Complexes

Keywords: Iron / Lithium / Aryloxides / Oxide precursors / Homogeneous catalysis 